\title{
Gaviscon: not always entirely safe!
}

\section{Asha Shenvi}

Neonatal Unit, Birmingham Heartlands Hospital, Birmingham, UK

\section{Correspondence to}

Dr Asha Shenvi, ashashenvi@yahoo.com
To cite: Shenvi A. BMJ Case Reports Published online: [Please include Day Month Year] doi:10.1136/bcr-2012 007866

\section{DESCRIPTION}

A $27^{+2}$ week gestation baby had a relatively uneventful initial neonatal course. At 3 weeks age, her feeds were increased to $200 \mathrm{ml} / \mathrm{kg} / \mathrm{day}$ to optimise weight gain. She subsequently developed recurrent desaturations that were felt to be secondary to reflux. Gaviscon was added to her milk. She tolerated her feeds well and there were no abdominal symptoms apart from a full abdomen. However, her desaturations continued and $48 \mathrm{~h}$ later a chest $\mathrm{x}$-ray was done to evaluate a respiratory cause of her desaturations. The $\mathrm{x}$-ray showed a large mass lining the stomach (figure 1) which was confirmed by a barium meal. This was felt to be a gaviscon bezoar. Gaviscon was discontinued and a repeat abdomen $\mathrm{x}$-ray 2 days later showed complete resolution of the mass.

Infant gaviscon is used commonly in the treatment of gastro-oesophageal reflux in premature neonates.

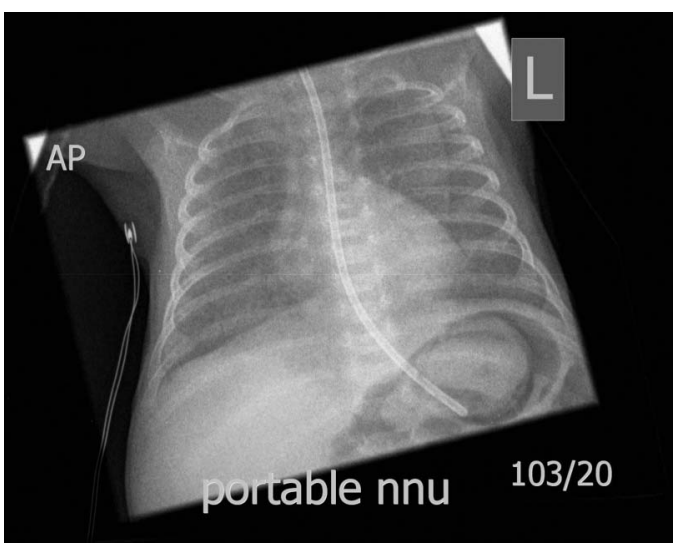

Figure 1 Gastric mass visualised on chest x-ray.
It is considered to be a relatively safe drug by clinicians. Gaviscon bezoar or 'gavisconoma' has been described as early as $1976^{1}$ and possibly occurs more commonly than diagnosed. ${ }^{2}$ We note from this case that bezoars can develop as early as $48 \mathrm{~h}$ after starting gaviscon in a preterm infant. They resolve spontaneously after stopping gaviscon (within $48 \mathrm{~h}$ in our case). ${ }^{1-3}$

Clinicians must be aware of this possible unwanted side effect, which may eventually cause intestinal obstruction at a later stage.

\section{Learning points}

- Gaviscon should be stopped immediately once a 'gavisconoma' is diagnosed. This will ensure avoidance of unnecessary surgical interventions at a late stage.

- A repeat radiograph is indicated over the next few days to ensure that complete resolution has occurred.

\section{Competing interests None.}

Patient consent Obtained.

Provenance and peer review Not commissioned; externally peer reviewed.

\section{REFERENCES}

1 Hewitt GJ, Benham ES. A complication of Gaviscon in a neonate - 'the Gavisconoma'. Aust Paediatr J 1976;12:47-8.

2 Sorbie AL, Symon DN, Stockdale EJ. Gaviscon bezoars. Arch Dis Child 1984;59:905-6.

3 Portuguez-Malavasi A, Aranda JV. Antacid bezoar in a newborn. Pediatrics 1979;63:679-80.

Copyright 2013 BMJ Publishing Group. All rights reserved. For permission to reuse any of this content visit http://group.bmj.com/group/rights-licensing/permissions.

BMJ Case Report Fellows may re-use this article for personal use and teaching without any further permission.

Become a Fellow of BMJ Case Reports today and you can:

- Submit as many cases as you like

- Enjoy fast sympathetic peer review and rapid publication of accepted articles

- Access all the published articles

- Re-use any of the published material for personal use and teaching without further permission

For information on Institutional Fellowships contact consortiasales@bmjgroup.com

Visit casereports.bmj.com for more articles like this and to become a Fellow 